\title{
Effect of nutritional factors on the culture of Nostoc sp. as a source of phycobiliproteins
}

\author{
Humberto J. Silva*, Teresa I. Cortiñas, and Rodolfo J. Ertola \\ Centro de Investigación y Desarrollo en Fermentaciones Industriales (CINDEFI), Facultad de Ciencias Exactas, UNLP, 47 y \\ 115, 1900, La Plata, Argentina
}

Summary. The effect of nutritional factors in a new culture medium $\left(\mathrm{BW}_{3}\right)$ is described for the cyanobacterium Nostoc sp. The growth of Nostoc sp. was higher in $\mathrm{BW}_{3}$ than in control media currently used for cyanobacteria. With medium $\mathrm{BW}_{3}$ the content of the pigment c-phycocyanin depended on the culture conditions employed, particularly the nature of the nitrogen and carbon sources. Higher amounts of c-phycocyanin amounting to $20.1 \%$ on a dry-weight basis were accumulated when both sources were supplied in the gas phase of the culture. The phycobiliproteins of Nostoc sp. were resolved into two components: c-phycocyanin $\left(\lambda_{\max }=614 \mathrm{~nm}\right)$ and allophycocyanin $\left(\lambda_{\max }=652 \mathrm{~nm}\right)$. The phycobiliprotein composition was $30 \%$ allophycocyanin and $70 \%$ c-phycocyanin. The culture of Nostoc sp. in $\mathrm{BW}_{3}$ medium seems promising as a source of biomass for the production of natural dyes.

\section{Introduction}

For the production of mass cultures of cyanobacteria, the use of reliable culture media which can sustain good growth of the selected strain is a necessary prerequisite. The literature contains many media suitable for cultivating pure species of cyanobacteria. In some cases a small number of media are effective in the maintenance of a large and diverse collection of cyanobacteria (Rippka et al. 1979). However, they are usually not optimized

\footnotetext{
* Present address: Laboratorio de Alimentos, Universidad Nacional de San Luis, Chacabuco y Pedernera, 5700, San Luis, Argentina

Offprint requests to: $\mathbf{H}$. J. Silva
}

for the production of mass cultures, especially when a new strain is isolated.

The most striking characteristic of cyanobacteria is the presence of brilliantly coloured accessory pigments, the phycobiliproteins. The high levels of phycobiliproteins that cyanobacteria can accumulate under favourable environmental conditions (Myers and Kratz 1955) make them attractive as a source of natural pigments for food products such as beverages and dry beverage mixtures (Langston and Maing 1983). These proteins are also widely used as fluorescent tags in a variety of diagnostic and research applications (Glazer and Stryer 1984; Kronick 1986).

This paper describes the results obtained with a culture of a strain of Nostoc, a filamentous heterocystous cyanobacterium, using a culture medium particularly designed for the strain. Growth and pigment content of the alga in batch cultures were analysed under different nutritional conditions. The purification and initial characterization of the phycobiliproteins of Nostoc are also presented.

\section{Materials and methods}

Strain isolation. A slimy algal material taken from brackish waters of the Province of San Luis, Argentina, was inoculated in media G II (Hughes et al. 1958) and BW (see Culture conditions) under continuous illumination. After 10 days a profuse growth of a heterocystous filamentous species of cyanobacterium was observed in $\mathrm{BW}_{3}$. Trichomes from the surface were inoculated first into fresh $\mathrm{BW}_{3}$ liquid medium and then onto $\mathrm{BW}_{3}$ agar medium. After 4-5 tranfers of the outer trichomes to $\mathrm{BW}_{3}$ agar-slant medium, a Nostoc sp. strain free from other algae was obtained. The strain identification (performed by Dr. S. Guarrera, Museum of Natural Sciences, Phycology Division, UNLP, La Plata, Argentina) was based on structural properties determined by light microscopy. The strain was kept in liquid and agar $\mathrm{BW}_{3}$ medium. 
Cultivation conditions. Several culture media (referred to as $\mathrm{BW}$ ) were tested for their ability to support growth of the Nostoc sp. They were obtained by varying the concentration of salts of a nutrient solution used for the culture of Chlorella (Silva and Pirt 1984). The $\mathrm{BW}_{3}$ medium finally used contained, per litre: $\mathrm{KH}_{2} \mathrm{PO}_{4}, 0.25 \mathrm{~g} ; \mathrm{NaHCO}_{3}, 0.5 \mathrm{~g} ; \mathrm{MgSO}_{4} \cdot 7 \mathrm{H}_{2} \mathrm{O}, 0.37 \mathrm{~g}$; $\mathrm{CaCl}_{2} \cdot 2 \mathrm{H}_{2} \mathrm{O}, 40.0 \mathrm{mg} ; \mathrm{FeCl}_{3} \cdot 6 \mathrm{H}_{2} \mathrm{O}, 24.0 \mathrm{mg} ; \mathrm{Na}_{2}$ ethylenediaminetetraacetic acid (EDTA) $2 \mathrm{H}_{2} \mathrm{O}, \quad 85.4 \mathrm{mg}$; $\mathrm{ZnSO}_{4} \cdot 7 \mathrm{H}_{2} \mathrm{O}, \quad 4.5 \mathrm{mg} ; \quad \mathrm{Na}_{2} \mathrm{MoO}_{4} \cdot 2 \mathrm{H}_{2} \mathrm{O}, \quad 2.5 \mathrm{mg}$; $\mathrm{CuSO}_{4} \cdot 5 \mathrm{H}_{2} \mathrm{O}, 2.0 \mathrm{mg} ; \mathrm{MnSO}_{4} \cdot 4 \mathrm{H}_{2} \mathrm{O}, 4.0 \mathrm{mg} ; \mathrm{Na}_{2} \mathrm{~B}_{4} \mathrm{O}_{7} \cdot 7 \mathrm{H}_{2} \mathrm{O}$, $8.7 \mathrm{mg} ; \mathrm{NaVO}_{3}, 0.12 \mathrm{mg} ; \mathrm{CoCl}_{2} \cdot 6 \mathrm{H}_{2} \mathrm{O}, 1.25 \mathrm{mg} ; \mathrm{NiSO}_{4} \cdot 7 \mathrm{H}_{2} \mathrm{O}$, $0.20 \mathrm{mg}$. The $\mathrm{BW}_{3}$ medium was made up in the following five solutions, which were autoclaved separately at 1 atmosphere for $15 \mathrm{~min}$ and then mixed after colling: (a) $\mathrm{KH}_{2} \mathrm{PO}_{4}$ and $\mathrm{NaHCO}_{3}$ adjusted to pH 7.5 with $\mathrm{NaOH}$, (b) $\mathrm{CaCl}_{2}$ and $\mathrm{MgSO}_{4}$, (c) $\mathrm{FeCl}_{3}+\mathrm{EDTA}$ (2 mol per mol $\mathrm{Fe}$ ), (d) other salts + EDTA (1 mol per mol metal) adjusted to $\mathrm{pH} 7$ with $\mathrm{NaOH}$, (e) $\mathrm{NaCl}$. Nitrogen-free media GII (Hughes et al. 1958 ) and C (Kratz and Myers 1955) were used as controls; $\mathrm{NaCl}(2 \mathrm{~g} / 1)$ was added to all the media employed.

The biomass was determined by dry weight measurements. The cells were centrifuged, washed twice with distilled water and dried at $100^{\circ} \mathrm{C}$ for $16 \mathrm{~h}$. The specific growth rate was calculated by the expression: $\ln x / x_{0} \cdot t^{-1}$ in the logarithmic phase of growth (Pirt 1975), where $x_{0}=$ initial biomass concentration ( $\mathrm{g}$ dry weight. $1^{-1}$ ) and $x=$ biomass concentration at time $t$.

Serum bottles of $500 \mathrm{ml}$ containing $250 \mathrm{ml}$ culture medium were used for growth. The serum bottles were injected with gas every $24 \mathrm{~h}$ and stoppered with rubber bungs. The $\mathrm{pH}$ was manually controlled at 7.5 . The cultures were agitated on a rotary shaker at $100 \mathrm{rpm}$ and incubated at $30^{\circ} \pm 0.5^{\circ} \mathrm{C}$ in a Psycro-Therm Controlled Environment Shaker (New Brunswick Scientific, Edison, NJ, USA) under continuous illumination of $12.2 \mathrm{~J} \cdot \mathrm{cm}^{-1}$ per hour (fluorescent tubes).

Analytical methods. Chlorophyll a and total carotenoids were determined in $80 \% \mathrm{v} / \mathrm{v}$ acetone extracts of cells incubated for $30 \mathrm{~min}$ at $30^{\circ} \mathrm{C}$ and then for $16 \mathrm{~h}$ at $4^{\circ} \mathrm{C}$. Chlorophyll a and total carotenoid concentrations were calculated according to McKinney (1941) in the supernatants at $663 \mathrm{~nm}$ and $460 \mathrm{~nm}$ respectively after the acetone extracts were centrifuged at $15000 \mathrm{rpm}$ for $10 \mathrm{~min}$. For the extraction of phycobiliproteins, wet cells were suspended in $30 \mathrm{~m} M$ Na-phosphate buffer, $\mathrm{pH}$ 7. The water-soluble proteins were released by two freezing and thawing steps followed by incubation at $4^{\circ} \mathrm{C}$ for $96 \mathrm{~h}$ in the dark. The slurry was centrifuged at $10000 \mathrm{rpm}$ for $1 \mathrm{~h}$, and the supernatant was spared for the purification step. The concentration of c-phycocyanin was determined spectrophotometrically by using the specific extinction coefficient $E_{1 \mathrm{~cm}}^{1 \%}=67.5$ at $614 \mathrm{~nm}$, the principal absorption maximum (see Spectroscopic measurements).

Purification of phycobiliproteins. Lyophilised water-soluble extract $(0.5 \mathrm{~g})$ was suspended in $30 \mathrm{ml}$ of $30 \mathrm{mM}$ Na-phosphate buffer, $\mathrm{pH} 7$, containing $2 \mathrm{~m} M$ sodium azide, and the solution was fractionated stepwise with ammonium sulphate. The precipitates of the $0 \%-20 \%, 20 \%-45 \%, 45 \%-65 \%$ and $65 \%-75 \%$ saturated $\left(\mathrm{NH}_{4}\right)_{2} \mathrm{SO}_{4}$ solutions were resuspended in $25 \mathrm{ml}$ of $30 \mathrm{~m} M$ Na-phosphate buffer, $\mathrm{pH} \mathrm{7}$, containing $0.15 \mathrm{M} \mathrm{NaCl}$ and dialysed against 21 of the same buffer overnight. Each fraction was chromatographed on a DEAE-Sephadex A 50 column (Pharmacia Fine Chemicals, Uppsala, Sweden). The column $(1 \times 12$ active bed, pre-equilibrated with $0.15 \mathrm{M} \mathrm{NaCl}$, $30 \mathrm{~m} M$ Na-phosphate buffer, $\mathrm{pH}$ 7) was developed with a linear gradient of $0.15-0.45 M \mathrm{NaCl}$ in $30 \mathrm{~m} M$ Na-phosphate buffer, $\mathrm{pH} \mathrm{7,} \mathrm{using} \mathrm{a} \mathrm{total} \mathrm{volume} \mathrm{of} 60 \mathrm{ml}$. Fractions of $3 \mathrm{ml}$ were collected and their absorption recorded at 280, 570,614 and $652 \mathrm{~nm}$. The fractions with the highest $\mathrm{A}_{614} / \mathrm{A}_{280}$ (c-phycocyanin) and $\mathrm{A}_{652} / \mathrm{A}_{280}$ (allophycocyanin) ratios were pooled and the absortion spectra recorded.

Spectroscopic measurements. Room temperature spectra were obtained with a Beckman 25 recording spectrophotometer (Beckman Instruments, Palo Alto, Calif, USA). The c-phycocyanin extinction coefficient was determined according to O'Carra (1965) using the purified fractions with the highest $\mathrm{A}_{614} / \mathrm{A}_{280}$.

Polyacrylamide gel electrophoresis (PAGE). Sodium dodecyl sulphate (SDS)-PAGE of the fractions precipitated with $\left(\mathrm{NH}_{4}\right)_{2} \mathrm{SO}_{4}$ and dialysed against $30 \mathrm{mM}$ Na-phosphate buffer, $\mathrm{pH} 7$, was performed by the method of Laemmli (1970). The polyacrylamide slab gels $(1.5 \mathrm{~mm}$ thickness) were prepared with $30 \%$ acrylamide $-0.8 \%$ methylene bisacrylamide in TRIS/ $\mathrm{HCl}$ buffer, $\mathrm{pH}$ 8.8. The electrophoresis was carried out at $25^{\circ} \mathrm{C}$. The gels were stained with Coomassie Brilliant Blue R250. Protein determination was performed according to Lowry et al. (1951).

\section{Results and discussion}

\section{Influence of nutritional factors on growth}

In initial experiments the growth of Nostoc sp. using different media was compared. Best growth occurred in $\mathrm{BW}_{3}$ medium $(0.75 \mathrm{~g} / \mathrm{l})$ compared to that obtained in media $\mathrm{C}$ and G II $(0.22 \mathrm{~g} / 1$ and $0.11 \mathrm{~g} / 1$, respectively) at $192 \mathrm{~h}$ of culture.

The major differences between the media used were the absence of any salt containing combined nitrogen in $\mathrm{BW}_{3}$ medium and the concentrations of iron, zinc, copper and cobalt. In addition, the salts of vanadium and nickel present in $\mathrm{BW}_{3}$ were absent in media C and G II. The level of iron in $\mathrm{BW}_{3}$ was $4.8 \mathrm{ppm}$, almost five times the optimum of $1 \mathrm{ppm}$ reported for the growth of Nostoc muscorum on $\mathrm{N}_{2}$, but half the amount needed for growth on nitrate (Eyster 1972). The concentration of molybdenum in $\mathrm{BW}_{3}$ medium $\left(1 \times 10^{-6} M\right)$ was ten times higher than the optimum reported for the growth of cyanobacteria on $\mathrm{N}_{2}$ (Eyster 1972).

The $\mathrm{BW}_{3}$ medium was used as basal medium for further experiments, which included variations in the concentration of $\mathrm{NaCl}$, the source of carbon and nitrogen and the composition of the gas phase. The values of the biomass, specific growth rate and pigment composition of the cells were determined (Table 1). Nostoc sp. has specific requirements for $\mathrm{NaCl}$ although it showed little tolerance to it. Cultures grown in the presence of $4.5 \mathrm{~g} \mathrm{NaCl} / 1$ and $9 \mathrm{~g} \mathrm{NaCl} / 1$ showed higher values of specific growth rate and biomass respectively, while cultures grown in the presence of $18 \mathrm{~g} \mathrm{NaCl} / 1$ were completely inhibited. 
Table 1. Growth of Nostoc sp. in $\mathrm{BW}_{3}$ medium with various added nutrients under different gas phases ${ }^{\mathrm{a}}$

\begin{tabular}{|c|c|c|c|c|c|c|}
\hline \multirow{2}{*}{$\begin{array}{l}\text { Addition }^{\mathrm{b}} \\
(\mathrm{g} / \mathrm{l})\end{array}$} & \multirow[t]{2}{*}{ Gas phase } & \multirow{2}{*}{$\begin{array}{l}\text { Biomass }^{c} \\
(\mathrm{~g} / 1)\end{array}$} & \multirow{2}{*}{$\begin{array}{l}\text { Specific } \\
\text { growth } \\
\text { rate }\left(h^{-1}\right)\end{array}$} & \multicolumn{3}{|c|}{$\begin{array}{l}\text { Pigment concentration ( } \% \text { dry } \\
\text { weight) }\end{array}$} \\
\hline & & & & $\begin{array}{l}\text { Chloro- } \\
\text { phyll a }\end{array}$ & $\begin{array}{l}\text { Total } \\
\text { caro- } \\
\text { tenoids }\end{array}$ & $\begin{array}{l}\text { c-Phyco- } \\
\text { cyanin }\end{array}$ \\
\hline $\mathrm{NaCl}(2)$ & $3 \% \mathrm{CO}_{2}: 97 \% \mathrm{~N}_{2}$ & 0.368 & 0.009 & 1.47 & 0.27 & 20.10 \\
\hline $\mathrm{NaCl}(4.5)$ & $3 \% \mathrm{CO}_{2}: 97 \% \mathrm{~N}_{2}$ & 0.403 & 0.014 & 1.48 & 0.28 & 20.10 \\
\hline $\mathrm{NaCl}(9)$ & $3 \% \mathrm{CO}_{2}: 97 \% \mathrm{~N}_{2}$ & 0.485 & 0.001 & 1.46 & 0.31 & 20.18 \\
\hline $\mathrm{NaCl}(18)$ & $3 \% \mathrm{CO}_{2}: 97 \% \mathrm{~N}_{2}$ & No growth & & & & \\
\hline $\mathrm{KNO}_{3}(1) ; \mathrm{NaHCO}_{3}(4.5) ; \mathrm{NaCl}(4.5)$ & Air & 0.515 & 0.014 & 2.04 & 0.26 & 13.47 \\
\hline Urea (0.3); $\mathrm{NaHCO}_{3}(4.5) ; \mathrm{NaCl}(4.5)$ & Air & 0.367 & 0.009 & 1.73 & 0.27 & 9.75 \\
\hline $\mathrm{NH}_{4} \mathrm{Cl}(0.5) ; \mathrm{NaHCO}_{3}(4.5) ; \mathrm{NaCl}(4.5)$ & Air & 0.128 & 0.007 & 1.80 & 0.25 & 11.50 \\
\hline $\mathrm{KNO}_{3}(1) ; \mathrm{NaCl}(4.5)$ & $3 \% \mathrm{CO}_{2}: 97 \%$ air & 0.211 & 0.011 & 1.70 & 0.26 & 9.40 \\
\hline Urea $(0.3) ; \mathrm{NaCl}(4.5)$ & $3 \% \mathrm{CO}_{2}: 97 \%$ air & 0.461 & 0.014 & 1.72 & 0.32 & 12.37 \\
\hline $\mathrm{NaHCO}_{3}(4.5) ; \mathrm{NaCl}(4.5)$ & $\mathrm{N}_{2}$ & 0.332 & 0.014 & 1.98 & 0.33 & 10.46 \\
\hline
\end{tabular}

a Nostoc sp was cultured in $500-\mathrm{ml}$ serum bottles containing $250 \mathrm{ml} \mathrm{BW} 3$ medium, stoppered with rubber bungs, at $30^{\circ} \pm 0.5^{\circ} \mathrm{C}$ under warm white fluorescent illumination and agitated in a rotary shaker at $100 \mathrm{rpm}$. The pH was manually controlled to 7.5 every $24 \mathrm{~h}$ at which time the cultures were bubbled with the gas phase indicated for $5 \mathrm{~min}$

${ }^{b}$ Additions were made to $\mathrm{BW}_{3}$ while keeping the other components constant

${ }^{\mathrm{c}}$ Biomass dry-weight at $144 \mathrm{~h}$ of culture

It was observed that the $\mathrm{BW}_{3}$ medium supported good growth of Nostoc sp. if the sources of carbon and nitrogen were either supplied in the gas phase or included as mineral salts in the culture medium (Table 1). The same specific growth rate, $0.014 \mathrm{~h}^{-1}$, was observed both in the presence of sodium bicarbonate and nitrogen from nitrate and with a mixture of $3 \% \mathrm{CO}_{2}: 97 \% \mathrm{~N}_{2}$. However, when the nitrogen and carbon sources were included as salts in the culture media, the results obtained depended mainly on the nature of the nitrogen source. Growth was higher using $\mathrm{KNO}_{3}$, decreased with urea and was poor in the presence of $\mathrm{NH}_{4} \mathrm{Cl}$. As $\mathrm{BW}_{3}$ medium did not have sufficient buffer capacity, the $\mathrm{pH}$ drifted upwards with increasing cell density. These drifts in $\mathrm{pH}$ values to $8.5-10.5$ could have been particularly harmful in the case of using $\mathrm{NH}_{4} \mathrm{Cl}$ as the nitrogen source, because of the production of toxic levels of free ammonia. According to Azov and Goldman (1982) free ammonia can produce a $98 \%$ reduction in the rate of photoassimilation of ${ }^{14} \mathrm{C}$ in Scenedesmus obliquus growing with $10 \mathrm{mM} \mathrm{NH}{ }_{4} \mathrm{Cl}$ and $2 \mathrm{mM} \mathrm{NaHCO}$ at $\mathrm{pH} \mathrm{8.4.} \mathrm{If} \mathrm{only} \mathrm{the} \mathrm{nitrogen}$ source was included in the medium, growth was higher in the presence of urea than with $\mathrm{KNO}_{3}$. Sodium bicarbonate sustained good growth of Nostoc sp. using $\mathrm{N}_{2}$ in the gas phase.

The fact that $\mathrm{pH}$ was manually controlled to 7.5 in a discontinuous way imposed a restriction on the potential levels of biomass that could be achieved with Nostoc sp. in $\mathrm{BW}_{3}$ medium. At increasing cell concentrations, besides high values of $\mathrm{pH}$, light limitation can occur, resulting in the establishment of environmental conditions under which exponential growth is not produced. In fact, with the culture system employed, logarithmic growth was observed only in the first stages of the cultures. After $96 \mathrm{~h}$ there was a failure to maintain constant exponential growth in all the conditions analysed. Similar results were reported by Ward (1985) in batch cultures of Synechococcus leopoliensis.

\section{Influence of nutritional factors on pigment content}

The pigment content of Nostoc sp. cultivated in $\mathrm{BW}_{3}$ medium varied with the nutrients employed. The major variations were observed in the content of c-phycocyanin (Table 1). The highest content of c-phycocyanin was obtained with $\mathrm{CO}_{2}$ as carbon source and $\mathrm{N}_{2}$ as nitrogen source, with a mean value of $20.1 \%$ of the biomass dry weight in comparison with $11.5 \%$ when both sources were added as mineral salts to the culture medium. The content of c-phycocyanin remained fairly constant in the presence of $2.0,4.5$ and $9.0 \mathrm{~g} \mathrm{NaCl} / 1$, but varied markedly using $\mathrm{NaHCO}_{3}$ as carbon source, and $\mathrm{KNO}_{3}$, urea and $\mathrm{NH}_{4} \mathrm{Cl}$ as nitrogen sources. As c-phycocyanin not only acts as an accessory pigment in the transfer of light energy to chlorophyll a (Bogorad 1975), but also as a nitrogen storage compound in cyanobacteria (Boussiba and Richmond 1980), it is likely that its concentration within the cell will depend on various 
environmental conditions. This has been shown for the effect of light quality, light intensity, high temperature, $\mathrm{CO}_{2}$ concentration and nitrogen starvation (Tandeau de Marsac 1977; Goedheer 1976; Oquist 1974; Eley 1971; Allen and Smith 1969; Boussiba and Richmond 1980). The results reported in this work show that for the strain of Nostoc isolated the content of c-phycocyanin depends in part on nutritional factors, particularly the nature of the carbon and nitrogen sources. A study on the effect of other environmental conditions is planned.

\section{Purification and initial characterization of phycobiliproteins}

The absorption spectrum in the visible region of a crude water-soluble extract of Nostoc sp. is shown in Fig. 1A. The absorption maximum was observed at approximately $615 \mathrm{~nm}$ with a slight shoulder at $650 \mathrm{~nm}$. Ion exchange chromatography on DEAE-Sephadex A 50 of the $20 \%-45 \%$ $\left(\mathrm{NH}_{4}\right)_{2} \mathrm{SO}_{4}$ fraction resulted in the separation of c-phycocyanin and allophycocyanin. The absorption maxima of c-phycocyanin and allophycocyanin were $614 \mathrm{~nm}$ and $652 \mathrm{~nm}$, respectively (Fig. 1B, C). The specific absorption coefficient of c-phycocyanin was $E_{1 \mathrm{~cm}}^{1 \%}=67.5$. The phycobiliprotein composition was $30 \%$ allophycocyanin and $70 \%$ c-phycocyanin. The content of c-phyco-

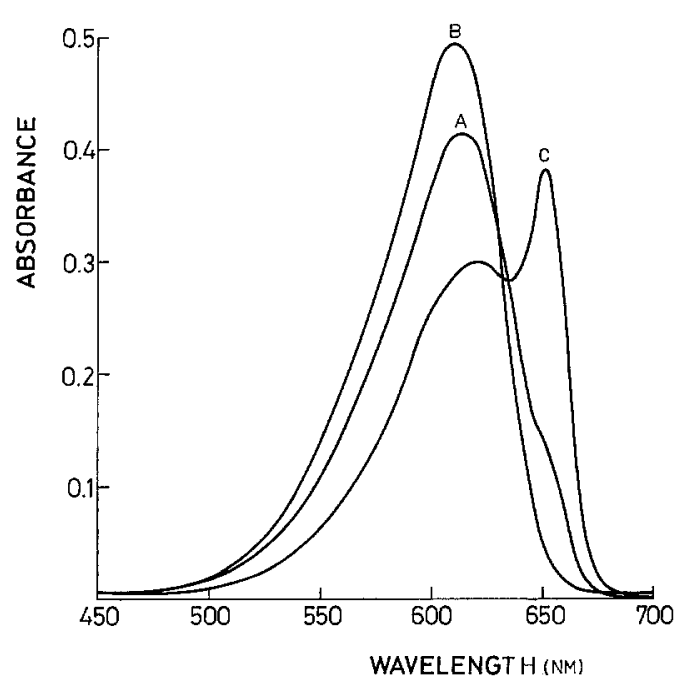

Fig. 1. Absorption spectra of Nostoc sp.: $A$, crude water-soluble extract; $B$, c-phycocyanin; $C$, allophycocyanin. c-Phycocyanin and allophycocyanin were purified by ion exchange chromatography of the $20 \%-45 \%$ ammonium sulphate fraction from a column of DEAE-Sephadex A 50 cyanin was similar to that of the endophytic cyanobacterium Anabaena azollae (Tyagi et al. 1980).

Phycobiliproteins are the main light-harvesting pigments of photosynthesis in cyanobacteria. Whereas the phycobiliproteins c-phycocyanin and allophycocyanin are always present (Yamanaka and Glazer 1981) more variation is found in the occurrence of additional phycobiliproteins such as c-phycoerythrin $\left(\lambda_{\max }\right.$ at $\left.565 \mathrm{~nm}\right)$ and phycoerythrocyanin $\left(\lambda_{\max }\right.$ at $\left.568 \mathrm{~nm}\right)$ (Stanier and Cohen-Bazire 1977; Eder et al. 1978). The c-phycocyanin absorption maximum at $614 \mathrm{~nm}$ of Nostoc sp. is the same as that reported in Anabaena sp. 6411 and A. variabilis (Bryant et al. 1976). The absorption maximum of allophycocyanin $\left(\lambda_{\max }\right.$ at $652 \mathrm{~nm}$ ) is similar to allophycocyanins from other unicellular and filamentous species (Cohen-Bazire et al. 1977; Bryant et al. 1981; Boussiba and Richmond 1979). Unlike the majority of other strains of Nostoc from the Pasteur Culture Collection (Rippka et al. 1979) the strain isolated does not produce either c-phycoerythrin or phycoerythrocyanin. Allophycocyanin B $\left(\lambda_{\max }\right.$ at $\left.670 \mathrm{~nm}\right)$ which is reported to be present in almost all cyanobacteria (Glazer and Bryant 1975) was also not detected. Similar results were found in the characterization of the phycobiliproteins of Gloeobacter violaceus (Bryant et al. 1981).

Polyacrylamide gel electrophoresis in the presence of SDS of the different fractions precipitated with $\left(\mathrm{NH}_{4}\right)_{2} \mathrm{SO}_{4}$ showed that there was no precipitation of proteins other than c-phycocyanin and allophycocyanin until the $45 \%-60 \%$ fraction was reached (data not shown). From 45\%-60\% onwards, in addition to the bands of c-phycocyanin and allophycocyanin, a number of bands appeared which corresponded to unidentified proteins and polypeptides. Protein determinations according to Lowry et al. (1951) on the different $\left(\mathrm{NH}_{4}\right)_{2} \mathrm{SO}_{4}$ fractions showed that, with the addition of $\left(\mathrm{NH}_{4}\right)_{2} \mathrm{SO}_{4}$ to $45 \%$ saturation, approximately $80 \%$ of the total phycobiliproteins present in the soluble extract was precipitated free from other proteins and polypeptides. If we also consider that the content of c-phycocyanin may be up to $20.1 \%$ on dry weight basis, and can be easily released from the cells, the culture of Nostoc sp. in $\mathrm{BW}_{3}$ medium seems promising as a source of biomass for the production of natural dyes.

Acknowledgements. This research was supported by the CONICET (Consejo Nacional de Investigaciones Científicas y Técnicas) of the Argentine Republic. Thanks are due to Ms Mirta Falochi for technical assistance. 


\section{References}

Allen MM, Smith AJ (1969) Nitrogen chlorosis in blue-green algae. Arch Mikrobiol 69:114-120

Azov Y, Goldman JC (1982) Free ammonia inhibition of algal photosynthesis in intensive cultures. Appl Environ Microbiol 43:735-739

Bogorad L (1975) Phycobiliproteins and complementary chromatic adaptation. Ann Rev Plant Physiol 26:369-401

Boussiba S, Richmond A (1979) Isolation and purification of phycocyanins from the blue-green alga Spirulina platensis. Arch Microbiol 120:155-159

Boussiba S, Richmond A (1980) c-Phycocyanin as a storage protein in the blue-green alga Spirulina platensis. Arch Microbiol 125:143-147

Bryant DA, Glazer AN, Eiserling FA (1976) Characterization and structural properties of the major biliproteins of Anabaena sp. Arch Microbiol 110:61-75

Bryant DA, Cohen-Bazire G, Glazer AN (1981) Characterization of the biliproteins of Gloeobacter violaceus. Chromophore content of a cyanobacterial phycoerythrin carrying phycourobilin chromophore. Arch Microbiol 129:190-198

Cohen-Bazire G, Beguin S, Rimon S, Glazer AN, Brown DM (1977) Physicochemical and immunological properties of allophycocyanins. Arch Microbiol 111:225-238

Eder J, Wagenmann R, Rudiger W (1978) Immunological relationship between phycoerythrins from various blue-green algae. Immunochemistry 15:315-321

Eley JH (1971) Effect of carbon dioxide concentration on pigmentation in the blue-green alga Anacystis nidulans. Plant Cell Physiol 12:311-316

Eyster C (1972) Mineral requirements of Nostoc muscorum for nitrogen fixation. In: Desikachary TV (ed) Taxonomy and biology of blue-green algae. University of Madras, Madras, pp 508-520

Glazer AN, Bryant DA (1975) Allophycocyanin B ( $\lambda_{\max } 671$, $618 \mathrm{~nm}$ ). A new cyanobacterial phycobiliprotein. Arch Microbiol 104:15-22

Glazer AN, Stryer L (1984) Phycofluor probes. Trends Biochem Sci 9:423-427

Goedheer JC (1976) Spectral properties of the blue-green alga Anacystis nidulans grown under different environmental conditions. Photosynthetica 10:411-422

Hughes EO, Gorham PR, Zehnder A (1958) Toxicity of a unialgal culture of Microcystis aeruginosa. Can J Microbiol 4:225-226

Kratz WA, Myers J (1955) Nutrition and growth of several blue-green algae. Am J Bot 42:282-287
Kronick MN (1986) The use of phycobiliproteins as fluorescent labels in immunoassay. J Immunol Methods 92:1-13

Laemmli UK (1970) Cleavage of structural proteins during the assembly of the head of bacteriophage $T 4$. Nature 227:680-685

Langston MK, Maing I (1983) Acid soluble blue colorant for food products. US patent no. 4400400

Lowry OH, Rosebrough NJ, Farr AL, Randall BJ (1951) Protein measurements with the Folin phenol reagent. J Biol Chem 193:265-275

McKinney G (1941) Absorption of light by chlorophyll solutions. J Biol Chem 140:315-322

Myers J, Kratz KA (1955) Relation between pigment content and photosynthetic characteristics in a blue-green alga. $J$ Gen Physiol 39:11-22

O'Carra P (1965) Purification and N-terminal analyses of algal biliproteins. Biochem J 94:171-174

Oquist G (1974) Light-induced changes in pigment composition of photosynthetic lamellae and cell-free extracts obtained from the blue-green alga Anacystis nidulans. Physiol Plant 30:45-48

Pirt SJ (1975) Principles of microbe and cell cultivation, 1st edn. Blackwells, Oxford, pp 4-14

Rippka R, Deruelles J, Waterbury JB, Herdman M, Stainer RY (1979) Generic assignments, strain histories and properties of pure cultures of cyanobacteria. J Gen Microbiol 111:1-61

Silva HJ, Pirt SJ (1984) Carbon dioxide inhibition of photosynthetic growth of Chlorella. J Gen Microbiol 130:28332838

Stanier RY, Cohen-Bazire G (1977) Phototrophic prokaryotes: the cyanobacteria. Ann Rev Microbiol 31:225-274

Tandeau de Marsac N (1977) Occurrence and nature of chromatic adaptation in cyanobacteria. J Bacteriol 130:82-91

Tyagi VVS, Mayne BC, Peters GA (1980) Purification and initial characterization of phycobiliproteins from the endophytic cyanobacterium of Azolla. Arch Microbiol 128:4144

Ward B (1985) Control of $\mathrm{pH}$ and inorganic carbon in batch cultures of cyanobacteria. Biotechnol Lett 7:87-92

Yamanaka G, Glazer AN (1981) Dynamic aspects of phycobilisome structure: modulation of phycocyanin content of Synechococcus phycobilisomes. Arch Microbiol 130:23-30

Received 28 July 1988/Accepted 3 March 1989 